\title{
BYSSINOSIS AND COPD RATES AMONG FACTORY WORKERS MANUFACTURING HEMP AND JUTE
}

\author{
MUKREMIN ER ${ }^{1}$, SALIH A. EMRI ${ }^{2}$, AHMET U. DEMIR ${ }^{2}$, PETER S. THORNE ${ }^{3}$, YALCIN KARAKOCA ${ }^{4}$, \\ NAZMI BILIR ${ }^{5}$, and IZZETTIN Y. BARIS $^{2}$ \\ ${ }^{1}$ Ataturk Training and Research Hospital, Ankara, Turkey \\ Pulmonary Diseases Department \\ ${ }^{2}$ Hacettepe University, Ankara, Turkey \\ Faculty of Medicine, Department of Pulmonary Diseases \\ ${ }^{3}$ University of Iowa, Iowa City, USA \\ Department of Occupational and Environmental Health, Environmental Health Sciences Research Center \\ ${ }^{4}$ Istanbul Medical Park Hospital, Istanbul, Turkey \\ Department of Pulmonary Diseases and Interventional Bronchology \\ ${ }^{5}$ Hacettepe University, Ankara, Turkey \\ Faculty of Medicine, Department of Public Health
}

\begin{abstract}
Objectives: Prior studies have been performed on cotton textile plants throughout the world. This study was planned to identify the rate of byssinosis and chronic obstructive pulmonary disease (COPD) in hemp and jute workers and those who worked with both of them. Material and Methods: The study was realized in a factory which consecutively processed hemp and jute. The study enrollment included 266 people, 164 of whom were active workers and 102 were retired. A questionnaire, plain chest X-rays, physical examination and pulmonary function tests were performed. Dust levels were measured in various sections of the factory during $8 \mathrm{~h}$ work shifts. Endotoxin levels of various quality hemp fibers and dusts were measured. Results: The rate of byssinosis $(28.2 \%)$ was higher among the workers that who exposed to both jute and hemp dust. The frequency of chronic bronchitis in retired workers who previously smoked was higher (20\%) as compared to currently smoking workers (17\%). High dust levels were measured in some parts of the factory (mean $\left.(\mathrm{M})=2.69 \mathrm{mg} / \mathrm{m}^{3}\right)$. Working in dense dust areas, active smoking, being older than 40 years of age, being an ex-smoker, and working in the factory for a period exceeding 15 years were significantly associated with bronchitis and emphysema development. High endotoxin levels were determined for fine hemp dust (605 EU/mg), coarse hemp dust (336 EU/mg) and poor quality hemp fibers $(114 \mathrm{EU} / \mathrm{mg})$, whereas in fresh hemp stalks the level of endotoxin was determined to be lower $(0.27 \mathrm{EU} / \mathrm{mg})$. Conclusions: Because of high exposures to jute and hemp dusts that are associated with high byssinosis rates, personal protection and environmental hygiene is crucial to prevention of byssinosis.
\end{abstract}

Key words:

Byssinosis, Endotoxin, COPD, Hemp, Jute, Occupational health

Received: November 18, 2014. Accepted: March 4, 2015.

Corresponding author: M. Er, Ataturk Training and Research Hospital, Pulmonary Diseases Department, 06800 Bilkent, Ankara, Turkey (e-mail: mukreminer@hotmail.com). 


\section{INTRODUCTION}

It is known that exposure to the organic dusts of textile plants results in respiratory system complaints and pulmonary diseases like byssinosis, chronic bronchitis, asthma-like syndrome, reactive airway dysfunction syndrome (RADS), occupational asthma and emphysema [1-4]. The 1st scholar to draw attention to occupational diseases and byssinosis was the Italian physician, Bernardino Ramazzini in the 17th century. Ramazzini in his book "De morbis artificum diatriba" detailed the relationship between occupation and diseases [5]. With the onset of the industrial revolution, from the 2nd half of the 19th century, increased production in the textile sector resulted in augmentation of occupational diseases. In 1936, Prausnitz, a British physician, drew attention to byssinosis and, in 1950 Schilling provided a detailed description [6,7].

Byssinosis was first defined in cotton workers, but in later studies it was also shown in workers who inhaled the dust of hemp, flax, sisal, jute and other fiber plants [8-10]. Byssinosis has been studied mostly in cotton workers, but there have also been several studies performed among hemp and jute workers [11-18]. Eastern European data from the 1970s and 1980s described byssinosis frequency as $47-66 \%$ in people inhaling hemp dust $[11,12]$.

Byssinosis is the most known and specific work-related illness in the textile sector. The classic symptoms of byssinosis consist of fever, malaise, chest tightness and dyspnea. Symptoms in the early stages of the disease occur on Monday, after the weekend vacation. Previously it was called "Monday Fever" but in 1956 it was described as stage 1 byssinosis by Schilling, and as B1 in the revised byssinosis stages by the World Health Organization (WHO) and the U.S. National Institute for Occupational Safety and Health (NIOSH). At the early stage of byssinosis (B1) symptoms of chest tightness, fever and malaise are only seen on the 1st working day (Monday) and disappear in the following days. In the 2nd stage of the disease, defined as B2, the symptoms expand to other days of the week and progress apart from work. With the progression of the disease, permanent changes like chronic bronchitis and emphysema develop in the workers producing restriction in their effort capacity and decrease in quality of life attributable to respiratory failure. Respiratory system irritation symptoms and pulmonary function test parameters are also rated in the WHO classification $[18,19]$.

Diseases related to chronic bronchitis and local irritation symptoms (nasal, ocular), are seen more often in people who inhale the dusts of hard textile plants like jute and sisal than soft textile plants like cotton and hemp [13]. Inhaling jute dust results in chronic bronchitis, cough and wheezing whereas byssinosis frequency is quite low [1317]. On the other hand, the increase in byssinosis is seen when exposure to jute dust is accompanied by exposure to other plant dusts [20,21].

Etiopathogenesis of byssinosis and other respiratory system diseases caused by organic plant dusts arise principally from endotoxins from the cell wall of Gram negative bacteria [22-26].

Now, we know that endotoxins are major etiologic factor over developing byssinosis and other respiratory diseases. Myriad studies show that endotoxin exposure has a causal role over developing byssinosis. According to them, Monday sickness has been correlated with airborne endotoxin concentrations, but not exactly correlated with airborne dust concentrations.

Some studies respected those acute alterations in lung functions over the course of a Monday work-shift and significant correlation with airborne endotoxins. Previously, while byssinosis had been thought that restricted to workers with exposure to cotton, flax and hemp dust, similar effects among workers inhaling endotoxin contaminated dust in wool carpet factories, swine confinement centers, and animal feed mill facilities have been found in some studies. Also, endotoxin has a possible role in the etiology of hypersensitivity pneumonitis [23]. 
Another study revealed that past exposure to endotoxin was associated with reduced forced expiratory volume in $1 \mathrm{~s}\left(\mathrm{FEV}_{1}\right)$ level among retired cotton workers. Moreover, past exposure was more strongly associated with reduced $\mathrm{FEV}_{1}$ for those hired $<5$ years before baseline than for those who were hired $\geq 5$ years after baseline. The study showed that recent endotoxin exposure was significantly associated with byssinosis, chronic bronchitis, and chronic cough [24].

In a study, in which animal model rat has been used to assess the effects of occupational stresses and hazards on exposure to textile environment, the investigators of the study showed increased $\alpha$ - and $\beta$-globulins and decreased total proteins and albumin levels. Also, they found increased serum C-reactive protein levels. They suggest that inhaled particles in the textile environment have extrapulmonary activity besides the pulmonary effects [25].

Manufacturing of rope, cord and hawser from hemp may be seen in various parts of Turkey, especially in Western Anatolia and the Black Sea region. People often do this job from childhood in workshops without ventilation systems with substantial inhalation of hemp dust. Jute is a fibrous textile plant grown in India, Bangladesh and neighboring countries. It is one of the cheapest natural textile fibers and has the 2nd highest consumption in the world after cotton.

Cotton based textile manufacturing is one of the important industries in Turkey. Much more epidemiological studies have been made on the diseases caused by cotton dusts among textile workers in Turkey. The 1st of these studies performed in Turkey was made by Tokgoz in 1968 among cotton workers, but no Turkish study has been done regarding other plant dusts that cause byssinosis [26-30]. Our study was conducted in the only jute processing factory in Turkey, where unprocessed jute fibers that came from Bangladesh were turned into rope used for the backing of synthetic carpets, sackcloth, cord and hawser. The factory was established to process hemp fibers in 1947. In 1983, processing machinery was renewed to handle jute plants imported from Bangladesh. Our study was conducted during the processing of jute. This factory was selected to research the effects of both plants on the respiratory system and byssinosis prevalence among the workers.

This study is the 1st in Turkey that covers the occupational exposure in jute and hemp workers. We performed this study among the current and retired workers of this jute rope factory which processed hemp in the past, to assess the frequency of byssinosis and other airway diseases, the role of dust concentrations in respiratory tract symptoms and developed occupational lung diseases. In addition, endotoxin levels were measured for various quality hemp fibers and dusts to assess the role of endotoxins on the development of byssinosis.

\section{MATERIAL AND METHODS}

\section{Study design}

A cross-sectional survey was conducted in a factory manufacturing rope made of jute. The study was carried out between April 1997 and August 1998. A research team measured dust levels in the factory, administered questionnaires for workers and a control group, made physical inspections and chest X-rays, performed respiratory function tests and data analysis. This study was conducted in a textile factory located at Taskopru Province of Kastamonu City at the Northern Anatolia region of Turkey. Some workers of the factory working in jute processing also worked previously in processing hemp.

The factory was established for hemp processing in 1947 and continued till 1983, but as the machinery became old-fashioned, they were renewed to process jute plant imported from Bangladesh. Our study was done during this period. The factory ended its production in 2004 and moved to a new factory in Gaziantep. Thus, current working environment and the dust concentrations are not the same, so that it could not be known, whether or not the presented data is still applicable and valid. 
The goal of this study was to understand the effect of hemp dust and jute dust together and separately on the workers of the factory as well as the appearance of byssinosis frequency and other chronic pulmonary diseases when these dusts are inhaled over a long period of time.

\section{Study population}

This study was conducted in a jute rope factory on 164 current workers and 102 retired workers. Among current workers, 19 had also worked in hemp processing before 1983, 60 of them started working after 1983 and were exposed only to jute dust, 78 of them worked both in hemp and jute processing and were exposed to both dusts, and 7 had no dust exposure. Seventy-nine of the current workers were employed in high dust concentration areas according to our measurements including in the stock room, bundle opening and spreading, carding, winding and spinning sections (Photo 1). Fifty-one worked in low dust concentration areas including drawing, beaming and threading sections. Eight sections of the factory were characterized as follows:

- storage (stock room),

- bundle opening and spreading,

- softening,

- carding (breaker carding and finisher carding),

- drawing (thinning),

- spinning,

- winding,

- beaming (threading).

\section{Data collection}

Questionnaires

A questionnaire published by Rylander for evaluation of organic dust exposure was administered to both current and retired workers [31]. This questionnaire ascertained work history, respiratory system complaints and smoking status. Byssinosis symptoms for retired workers were ascertained from self-reporting of their past experiences.
Physical examination

Participants of the study went through an overall physical inspection especially on the respiratory system. Participants were checked for wheezing, any increase in their anterior-posterior chest diameter, intercostal retraction, cyanoses, percussion hyper-resonance and rhonchi were noted.

\section{Pulmonary function tests}

All the participants in the study went through pulmonary function tests. Measurements were taken by using a Vitalograph/Compact (England) spirometer. The spirometer was calibrated before pulmonary function tests. Participant's age, height and sex were noted. Each participant underwent 3 measurements and the best value was noted. Forced vital capacity (FVC), forced expiratory volume in $1 \mathrm{~s}\left(\mathrm{FEV}_{1}\right)$, forced vital capacity/forced expiratory volume in $1 \mathrm{~s}\left(\mathrm{FEV}_{1} / \mathrm{FVC}\right)$, peak expiratory flow rate (PEFR), maximal mid-expiratory flow rate (MMEFR) were measured.

\section{Chest X-rays}

All participants posterior-anterior (PA) chest X-rays were evaluated by 2 different physicians according to the 1980 International Labor Organization (ILO) pneumoconiosis assessment standards. Radiography findings like hyperlucency, diaphragm flattening, and emphysema presence were especially noted.

\section{Working environment dust measurement}

Ankara Occupational Health and Safety Center performed dust measurements in different parts of the factory during this study. Altogether 7 dust measurements were performed. A vertical elutriator operated at a flow rate of $7.4 \pm 0.2 \mathrm{l} / \mathrm{min}$ was used to measure the concentration of the dust in the areas of the workers. To collect the dusts inside of the vertical elutriator, Sartorius cellulose nitrate filters with pore diameter of $5 \mu \mathrm{m}$ were 

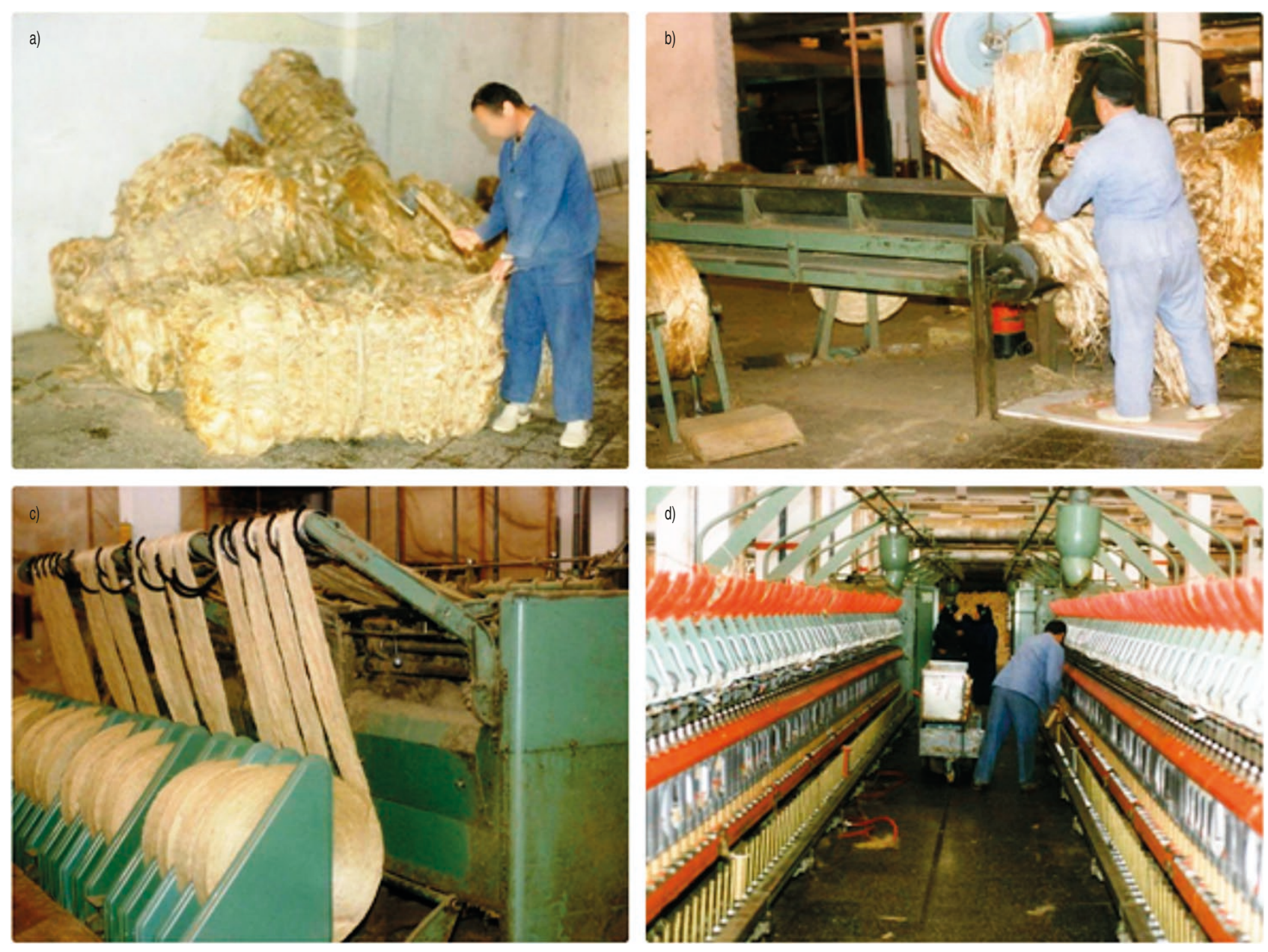

Photo 1. Dusty sections of the factory: a) opening and spreading, b) softening, c) carding, d) spinning

used. Dust concentrations were measured gravimetrically using a calibrated microbalance. As there are no accepted specific occupational exposure limits (OEL) in the world for hemp and jute dusts, the 8-h timeweighted average, permissible exposure limit (PEL) from the US Occupational Health and Safety Administration (OSHA) for cotton dust of $0.2 \mathrm{mg} / \mathrm{m}^{3}$ was selected as an acceptable OEL [32-34].

\section{Endotoxin level measurements}

Higher rates of byssinosis were determined in workers exposed to hemp dust, when compared to workers exposed to jute dust. We hypothesized that these might have been be due to a high endotoxin content of various parts of hemp and processed hemp dust. Thus, endotoxin measurements were conducted to investigate certain components of the hemp plant. Air sampling filters were not available for analysis of endotoxin. Thus, dust samples were taken from a nearby workshop, because the jute factory did not process hemp at that time. Endotoxin levels were measured in processed and unprocessed hemp plants and in hemp dust.

Endotoxin concentrations in the dust were measured using the Limulus Amebocyte Lysate assay (QCL-1000 LAL Assay, Lonza, Inc.) performed as previously described [35]. Samples were eluted into 
pyrogen-free water, were shaken for $60 \mathrm{~min}$ at room temperature and assayed against the Control Standard Endotoxin (EC-6 U.S. FDA Standard).

\section{Statistical analysis}

Epi Info 6.04 was used for basic statistical calculations. For logistic regression calculations, Windows SPSS 17.0 software was used. To examine the statistical significance of the differences among the results obtained from different groups, we used $\mathrm{Chi}^{2}$ test for the analysis of groups with more than 10 samples and Fisher's exact $\mathrm{Chi}^{2}$ test for the analysis of groups with fewer than 10 samples. A $p<0.05$ was used to determine significance of findings. The risk of getting chronic respiratory tract diseases caused by exposure to hemp and jute dust together or solitarily was calculated using logistic regression analysis by considering various factors like age, sex and smoking habit. Relative risks and odds ratios are presented along with $95 \%$ confidence intervals (CI).

\section{RESULTS}

\section{Dust measurements}

Airborne dust measurements were made in various sections of the factory. In most of these sections, dust levels were considerably higher than the U.S. OSHA occupational exposure limit of $0.2 \mathrm{mg} / \mathrm{m}^{3}$. High levels of dust concentration were found especially in bundle opening and spreading, carding, winding and spinning sections. In drawing, beaming and threading sections, dust concentrations were below the OEL (Table 1).

\section{Endotoxin level measurement findings}

High levels of endotoxin were detected especially in fine hemp dust (605 EU/mg), coarse hemp dust (336 EU/mg), poor quality hemp fibers (114 EU/mg), and lower levels in fresh hemp stalks (0.27 EU/mg) (Table 2). Endotoxin levels in jute plant and jute fiber dust were not assessed. Exposure to fine hemp dust at the mean exposure level
Table 1. Airborne dust concentrations measured in the sections of the factory

\begin{tabular}{lc}
\hline Factory section & $\begin{array}{c}\text { Dust concentration } \\
{\left[\mathrm{mg} / \mathrm{m}^{3}\right]}\end{array}$ \\
\hline Opening and spreading & $1.80^{*}$ \\
Carding & \\
finisher carding & $2.69^{*}$ \\
breaker carding & $0.98^{*}$ \\
Winding & $2.41^{*}$ \\
Spinning & $0.97^{*}$ \\
Drawing & 0.06 \\
Beaming and threading & 0.10 \\
\hline
\end{tabular}

* Dust concentration higher than the U.S. Occupational Health and Safety Administration (U.S. OSHA) permissible exposure limit (PEL) of $0.2 \mathrm{mg} / \mathrm{m}^{3}$.

Table 2. Endotoxin concentrations in various quality hemp dusts and fibers ${ }^{\mathrm{a}}$

\begin{tabular}{lc}
\hline \multicolumn{1}{c}{ Sample description } & $\begin{array}{c}\text { Endotoxin content } \\
{[\mathrm{EU} / \mathrm{mg}]}\end{array}$ \\
\hline Coarse hemp dust & 336.00 \\
Fine hemp dust & 605.00 \\
Hemp fiber quality & \\
good & 27.70 \\
fair & 47.00 \\
poor & 114.00 \\
Hemp stalk & 0.27 \\
Dried hemp leaves & 11.10 \\
\hline
\end{tabular}

a Samples for endotoxin analysis were obtained from multiple sections of factory while processing hemp.

observed in carding would suggest an extremely high endotoxin exposure level of $1600 \mathrm{EU} / \mathrm{m}^{3}$.

\section{Findings related to study population}

This study was carried out on a total of 266 employees of the jute processing factory, including 77 females $(29.3 \%)$ and 189 males (70.7\%). One hundred sixty-four participants (118 male and 46 female) were active workers, 102 participants ( 71 male, 31 female) were retired 
workers. There was no difference between groups in terms of gender. As expected, the average age of retired workers was higher and they were shorter. When a comparison is made regarding smoking habits, $76(46.3 \%)$ of the active workers and $57(55.9 \%)$ of retired workers have never smoked. Percentage of participants who quit smoking was higher in the retired employee group. Percentage of current smokers among active workers (39\%) was significantly higher than retired workers (18.6\%). Approximate pack-years of smoking were higher for active smokers and ex-smokers of the retired workers group (Table 3).
When active workers and retired workers are classified in terms of type of dust exposure, most of the active workers were exposed to jute alone and hemp plus jute in contrast with retired workers who were mostly exposed to hemp alone with fewer exposed to hemp plus jute. Although the rate of using a dust mask was low in both groups, nearly 3-times as many retired workers as current workers reported any use (30.4\% vs. $11.6 \%$ ) (Table 3$)$.

Pulmonary function test results of current and retired workers according to smoking status are presented in Table 3. As one would expect, the pulmonary function

Table 3. The demographic characteristics and status of habits of study participants

\begin{tabular}{|c|c|c|c|}
\hline Variable & $\begin{array}{l}\text { Current workers } \\
\quad(\mathrm{N}=164)\end{array}$ & $\begin{array}{l}\text { Retired workers } \\
\quad(\mathrm{N}=102)\end{array}$ & $\begin{array}{c}\text { Total } \\
(\mathrm{N}=266)\end{array}$ \\
\hline \multicolumn{4}{|l|}{ Gender [n (\%)] } \\
\hline females & $46(28.0)$ & $31(30.4)$ & $77(29.3)$ \\
\hline males & $118(72.0)$ & $71(69.6)$ & $189(70.7)$ \\
\hline Age [years] $(\mathrm{M} \pm \mathrm{SD})$ & $40.7 \pm 3.9$ & $61.1 \pm 10.3$ & $48.2 \pm 12$ \\
\hline Height $[\mathrm{cm}](\mathrm{M} \pm \mathrm{SD})$ & $165.2 \pm 8.0$ & $158.2 \pm 5.5$ & $162.7 \pm 7.9$ \\
\hline 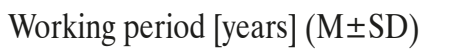 & $16.7 \pm 3.6$ & $21.1 \pm 5.2$ & $18.1 \pm 5.2$ \\
\hline \multicolumn{4}{|l|}{ Smoking status $[\mathrm{n}(\%)]$} \\
\hline never smoked & $76(46.3)$ & $57(55.9)$ & $140(50.0)$ \\
\hline former smoker & $24(14.6)$ & $26(25.5)$ & $53(18.9)$ \\
\hline current smoker & $64(39.0)$ & $19(18.6)$ & $87(31.1)$ \\
\hline \multicolumn{4}{|c|}{ Amount of smoking [pack-years] $(\mathrm{M} \pm \mathrm{SD})$} \\
\hline former smoker & $18.4 \pm 13.5$ & $41.3 \pm 38.6$ & $29.1 \pm 30.7$ \\
\hline current smoker & $25.3 \pm 11.9$ & $52.0 \pm 47.5$ & $32.1 \pm 27.2$ \\
\hline \multicolumn{4}{|l|}{ Dust exposure $[\mathrm{n}(\%)]$} \\
\hline hemp dust & 19 (11.6) & $61(59.8)$ & $80(28.6)$ \\
\hline jute dust & $60(36.6)$ & $7(6.9)$ & $67(23.9)$ \\
\hline hemp and jute dust & $78(47.6)$ & $27(26.5)$ & $105(37.5)$ \\
\hline no dust exposure & $7(4.3)$ & $7(6.9)$ & $28(10.0)$ \\
\hline \multicolumn{4}{|l|}{ Usage of dust mask [n (\%)] } \\
\hline never & $145(88.4)$ & $71(69.6)$ & $216(82.2)$ \\
\hline seldom & $13(7.9)$ & $16(15.7)$ & $29(13.2)$ \\
\hline frequent & $6(3.7)$ & $15(14.7)$ & $21(4.6)$ \\
\hline
\end{tabular}

M - mean; SD - standard deviation.

${ }^{\text {a }}$ Pack-year $=$ daily smoked packs of cigarette $\times$ smoked years. 
parameters were worse in smoking and retired workers (Table 4). Overall, retired workers had $\mathrm{FEV}_{1}$ and FVC values lower by $8 \%$ of predicted values than those currently employed. Importantly, there was a $9.2 \%$ loss of FVC and $7.7 \%$ loss of $\mathrm{FEV}_{1}$ among current workers who never smoked. Chest tightness and arthralgia were significantly greater in workers employed in relatively dusty environments than those in low dust areas.

All byssinotic complaints were more frequent in more highly exposed workers with significant differences seen for chest tightness, dyspnea, cough, lassitude and joint pain (Table 5).

Furthermore, feelings of tickling in the throat, nose itching, sneezing and local irritation symptoms such as skin itching were significantly higher in workers in high dust work areas (Table 6). Byssinosis symptoms for current workers exposed to hemp plus jute dust were significantly higher when compared to workers exposed only to jute dust. The prevalence of byssinosis symptoms among the retired workers with combined exposure to hemp and jute was twice as high as jute-only exposed retired workers, however, this difference did not reach significance

Table 4. The pulmonary function test parameters of the workers

\begin{tabular}{|c|c|c|c|c|c|c|c|c|}
\hline \multirow{3}{*}{$\begin{array}{c}\text { PFT } \\
\text { parameter }\end{array}$} & \multicolumn{8}{|c|}{$\begin{array}{c}\text { Smoking status } \\
{[\%]}\end{array}$} \\
\hline & \multicolumn{4}{|c|}{$\begin{array}{l}\text { current workers } \\
(\mathrm{N}=164)\end{array}$} & \multicolumn{4}{|c|}{$\begin{array}{l}\text { retired workers } \\
\quad(\mathrm{N}=102)\end{array}$} \\
\hline & NS & ES & CS & total & NS & ES & CS & total \\
\hline $\mathrm{VC}$ & 90.8 & 87.2 & 85.2 & 87.7 & 87.4 & 79.2 & 73.6 & 80.0 \\
\hline $\mathrm{EV}_{1}$ & 92.3 & 88.0 & 84.4 & 88.2 & 86.2 & 80.4 & 75.0 & 80.5 \\
\hline $\mathrm{FEV}_{1} / \mathrm{FVC}$ & 80.2 & 78.1 & 77.7 & 78.6 & 79.5 & 75.7 & 73.4 & 76.2 \\
\hline PEFR & 91.1 & 83.4 & 83.9 & 89.0 & 86.9 & 83.0 & 73.6 & 81.1 \\
\hline $\mathrm{MEF}_{25-75}$ & 93.5 & 88.9 & 87.2 & 88.3 & 89.3 & 81.1 & 78.7 & 83.0 \\
\hline
\end{tabular}

PFT - pulmonary function test; FVC - forced vital capacity; $\mathrm{FEV}_{1}$ forced expiratory volume in $1 \mathrm{~s} ; \mathrm{FEV}_{1} / \mathrm{FVC}$ - ratio of forced expiratory volume in $1 \mathrm{~s}$ and forced vital capacity; $\mathrm{MEF}_{25-75}$ - maximum expiratory flow at $25-75 \%$; \% - percent predicted.

NS - never smoked; ES - ever smoked; CS - current smoker.
Table 5. Comparison of byssinotic complaints of workers who work at sections with high density of dust and sections with low density of dust

\begin{tabular}{|c|c|c|c|}
\hline \multirow[t]{2}{*}{ Byssinotic sign } & \multicolumn{2}{|c|}{$\begin{array}{c}\text { Workers' group work } \\
\text { conditions } \\
{[\mathrm{n}(\%)]}\end{array}$} & \multirow[t]{2}{*}{$\mathrm{p}$} \\
\hline & $\begin{array}{l}\text { high dust }^{\mathrm{a}} \\
(\mathrm{N}=79)\end{array}$ & $\begin{array}{l}\text { low dust }{ }^{b} \\
(\mathrm{~N}=51)\end{array}$ & \\
\hline Chest tightness & $24(30.3)$ & $4(7.8)$ & 0.01 \\
\hline Dyspnea & $12(15.1)$ & $2(3.9)$ & 0.01 \\
\hline Wheezing & $5(6.3)$ & $1(1.9)$ & 0.07 \\
\hline Cough & $21(26.5)$ & $5(9.8)$ & 0.01 \\
\hline Fever & $6(7.5)$ & $2(3.9)$ & 0.06 \\
\hline Lassitude & $15(18.9)$ & $3(5.8)$ & 0.02 \\
\hline Joint pain & $12(15.1)$ & $1(1.9)$ & 0.01 \\
\hline Headache & $16(20.2)$ & $9(17.6)$ & 0.55 \\
\hline Nausea & $4(5.0)$ & $1(1.9)$ & 0.08 \\
\hline
\end{tabular}

a Sections with high dust are stock room, opening and spreading, carding (breaker carding, finisher carding), winding and spinning.

${ }^{\mathrm{b}}$ Sections with low dust are drawing, beaming and threading.

Table 6. Comparison of local irritation symptoms of workers who work at sections with high concentrations of dust and sections with low concentrations of dust

\begin{tabular}{llll}
\hline & \multicolumn{2}{c}{$\begin{array}{c}\text { Workers' group work } \\
\text { conditions } \\
\text { Local irritation } \\
\text { symptoms }\end{array}$} & \multicolumn{2}{c}{$[\mathrm{n}(\%)]$} \\
\cline { 2 - 3 } & $\begin{array}{c}\text { high dust } \\
(\mathrm{N}=79)\end{array}$ & $\begin{array}{c}\text { low dust } \\
(\mathrm{N}=51)\end{array}$ & \\
\hline Throat tickling & $19(24.0)$ & $3(7.8)$ & 0.01 \\
Nasal itching and sneezing & $18(22.7)$ & $2(3.9)$ & 0.01 \\
Eye burning & $11(13.9)$ & $3(5.8)$ & 0.03 \\
Skin itching & $15(18.9)$ & $1(1.9)$ & 0.01 \\
\hline
\end{tabular}

${ }^{\mathrm{a}, \mathrm{b}}$ As in Table 5 .

due to low numbers of retired workers with combined exposure (Table 7).

A significant relationship was found between chronic bronchitis, development of emphysema and risk factors such as working in high dust environments, being a smoker, being an ex-smoker, or working at this environment 
Table 7. Chronic diseases prevalence of current and retired workers according to dust exposure and smoking status

\begin{tabular}{|c|c|c|c|c|c|c|c|c|c|c|c|c|}
\hline \multirow{3}{*}{ Disease } & \multicolumn{6}{|c|}{$\begin{array}{l}\text { Current worker's exposure } \\
{[\mathrm{n}(\%)]}\end{array}$} & \multicolumn{6}{|c|}{$\begin{array}{l}\text { Retired worker's exposure } \\
{[\mathrm{n}(\%)]}\end{array}$} \\
\hline & \multicolumn{3}{|c|}{ jute dust } & \multicolumn{3}{|c|}{ hemp and jute dust } & \multicolumn{3}{|c|}{ jute dust } & \multicolumn{3}{|c|}{ hemp and jute dust } \\
\hline & $\begin{array}{c}\mathrm{NS} \\
(\mathrm{N}=23)\end{array}$ & $\begin{array}{c}E S \\
(N=37)\end{array}$ & $\begin{array}{c}\text { total } \\
(\mathrm{N}=60)\end{array}$ & $\begin{array}{c}\mathrm{NS} \\
(\mathrm{N}=42)\end{array}$ & $\begin{array}{c}\mathrm{ES} \\
(\mathrm{N}=36)\end{array}$ & $\begin{array}{c}\text { total } \\
(\mathrm{N}=78)\end{array}$ & $\begin{array}{c}\mathrm{NS} \\
(\mathrm{N}=25)\end{array}$ & $\begin{array}{c}E S \\
(N=36)\end{array}$ & $\begin{array}{c}\text { total } \\
(\mathrm{N}=61)\end{array}$ & $\begin{array}{c}\mathrm{NS} \\
(\mathrm{N}=14)\end{array}$ & $\begin{array}{c}E S \\
(N=13)\end{array}$ & $\begin{array}{c}\text { total } \\
(\mathrm{N}=27)\end{array}$ \\
\hline yssinosis & $3(13.0)$ & $2(5.4)$ & $5(8.3)$ & $10(23.8)^{*}$ & $12(33.3)^{*}$ & $22(28.2)^{*}$ & $5(20.0)^{*}$ & $7(19.4)$ & $12(19.6)$ & $6(42.8)^{*}$ & $5(38.4)^{*}$ & $11(40.7)^{*}$ \\
\hline $\begin{array}{l}\text { Chronic } \\
\text { bronchitis }\end{array}$ & $0(0.0)$ & $4(10.8)$ & $4(6.6)$ & $2(4.7)$ & $8(22.2)^{*}$ & $10(12.8)$ & $1(4.0)$ & $6(16.6)^{*}$ & $7(11.4)$ & $2(14.2)$ & $3(23.0)^{*}$ & $5(18.5)^{*}$ \\
\hline Emphysema & $1(4.3)$ & $4(10.8)$ & $5(8.3)$ & $2(4.7)$ & $5(13.8)^{*}$ & $7(8.9)$ & $4(16.0)$ & $6(16.6)^{*}$ & $10(16.4)^{*}$ & $1(7.1)$ & $4(30.7)^{*}$ & $5(18.5)^{*}$ \\
\hline
\end{tabular}

NS - never smoked; ES - ever smoked.

$* \mathrm{p}<0.05$. Comparison of statistical significance was computed only amongst current workers in the same dust exposure category and who have the same current smoking status.

Table 8. Logistic regression analysis showing odds ratios (OR) for association between dust exposure in the workplace, smoking and other confounding risk factors with chronic bronchitis, emphysema and byssinosis

\begin{tabular}{lccc}
\hline \multicolumn{1}{c}{ Risk factor } & \multicolumn{3}{c}{$\begin{array}{c}\text { Disease } \\
\text { OR (95\% CI) }\end{array}$} \\
\cline { 2 - 4 } & chronic bronchitis & emphysema & byssinosis \\
\hline Being a current worker & $0.38(0.09-1.62)$ & $0.40(0.10-1.60)$ & $0.47(0.06-3.52)$ \\
Being a retired worker & $0.65(0.16-1.98)$ & $0.62(0.18-2.15)$ & $0.89(0.13-6.28)$ \\
Employed in the working place > 15 years & $2.30(1.11-4.77)^{*}$ & $3.87(1.70-8.90)^{*}$ & $3.39(1.44-7.80)^{*}$ \\
Hemp dust exposure & $1.06(1.03-1.08)^{*}$ & $2.69(1.17-6.21)^{*}$ & $2.47(1.08-5.67)^{*}$ \\
Current smoking & $0.83(0.17-4.02)$ & $0.61(0.16-2.50)$ & $0.71(0.17-2.94)$ \\
Past smoking history & $2.06(1.06-3.97)^{*}$ & $1.44(0.36-5.70)^{*}$ & $0.80(0.11-5.93)$ \\
Working in the section with high dust & $0.66(0.29-1.48)$ & $2.50(0.44-14.14)^{*}$ & $4.74(0.51-43.98)^{*}$ \\
Working in the section with high dust and smoking & $6.10(1.17-31.65)^{*}$ & $11.97(1.99-72.42)^{*}$ & $8.88(1.40-56.37)^{*}$ \\
\hline
\end{tabular}

OR - odds ratio; $\mathrm{CI}$ - confidence interval.

* High risk.

more than 15 years. A significant relationship was found between the development of byssinosis and factors such as being an active worker plus smoker, being a retired worker plus ex-smoker and working at the factory more than 15 years and being exposed to hemp dust (Table 8).

\section{DISCUSSION}

Firstly, Prausnitz's and then Schilling's epidemiological study in England in 1950 determined that about 1/2 of the cotton workers had byssinosis, whereas today's studies show that this rate is reduced to $3 \%$ [6,7]. Research in Turkey has shown that byssinosis frequency in cotton workers is about 15-16\% [26-30]. Although byssinosis prevalence among cotton workers in Turkey has not fallen, as in more developed countries, with necessary precautions a decreasing trend is noticed. As far as we know, no prior research was made in Turkey to determine lung diseases among workers exposed to hemp and jute dust.

Most published studies about the respiratory diseases caused by plant dusts have been performed among cotton 
workers and few have addressed respiratory tract diseases from hemp and jute. In a 1996 study made by Fishwick et al., respiratory complaints were determined in $64 \%$ of hemp workers [9]. In the research of Zuskin et al., byssinosis frequency in hemp workers was found as $47-66 \%$, especially higher in smokers [12].

In the factory where we carried out our study, byssinosis frequency among retired workers was recorded as $26.2 \%$. Since we diagnosed byssinosis among retired workers according to their old respiratory system symptoms we might have determined a lower rate of byssinosis as compared to Zuskin's study. Our determination according to results of logistic regression analysis was that byssinosis risk is increased 4.74 times in retired smokers as compared to current workers, 3.39 times - in workers employed in the factory more than 15 years as compared to shorter duration-employed workers, and 2.47 times in workers exposed to hemp dust compared to workers who were exposed to jute dust.

In radiological and physical examination of retired hemp workers, emphysema was detected at around $26.2 \%$. This percentage was $27.7 \%$ in smokers and $24 \%$ in nonsmokers. Logistic regression analysis indicated that exposure to hemp dust may cause emphysema with an odds ratio of 2.69. Working in the factory more than 15 years increased the risk of emphysema 3.87 times, whereas in retired workers, being exposed to hemp dust and smoking, increased this risk 2.5 times. In a previous study, it was claimed that the rate of emphysema did not increase among cotton workers [20]. In our study, we determined emphysema in nonsmoking workers as well.

Worldwide studies of respiratory system diseases caused by exposure to jute dust figure that chronic bronchitis, coughing and wheezing frequency are found at the same rates as with the exposure to other fiber structured textile plants like cotton and hemp, whereas byssinosis frequency is lower. On the other hand, byssinosis frequency is higher when exposure to jute dust is present with other plant dusts [21]. In these studies it is also noted that chronic bronchitis, nasal and ocular irritation are on the front burner in the workers who inhaled the dusts of hard fibered textile plants like jute and sisal [13].

The results of this study are consistent with the results in these earlier studies. We found that average byssinosis rate in the workers who are exposed only to jute dust is $8.3 \%$, whereas in the jute workers who also worked in hemp processing the rate is higher $(28.2 \%)$. The complaints related to local irritation were more common in the workers employed in high dust sections like opening, spreading, ruffer and bobbin as compared to workers exposed only to jute dust. The difference between the workers in the low and high dust sections was statistically significant.

The rates of byssinotic complaints and chronic bronchitis were higher among the smoking workers. According to results of the logistic regression analysis, working in high dust sections and smoking at the same time increase chronic bronchitis risk 6-fold. Whether retired or active, more respiratory system complaints in smoking workers exposed to hemp or jute dust were detected, which confirms previous studies showing the additive effect of plant dusts with smoking in textile workers. Smoking results in increased risk for byssinosis caused by prolonged exposure to plant dusts like cotton, hemp and flax and also leads to nasal cancer caused by exposure to wood dust [36]. In order to avoid an additional risk from occupational exposures, workers should be encouraged not to take up smoking or to quit smoking if they already smoke. With the precautions in developed countries, byssinosis and its advanced stage chronic obstructive pulmonary disease (COPD) seen in textile workers in cotton mills, is showing a decreasing trend, whereas in Turkey this is still an important problem in textile workers processing fiber plants apart from cotton. Installation of engineering controls to decrease dust concentrations in textile-production factories should be taken as 
soon as possible and workers should be provided with respirators and a proper respiration fit program for further protection [37].

Although we observed lower byssinosis frequencies among workers exposed to only jute dust compared to only hemp dust and hemp dust plus jute dust, high rates of eye, nose and skin irritation symptoms were seen in current workers exposed to jute dust. This situation may arise because jute is a hard structured fiber as compared to cotton and hemp fibers. Jute fibers are less likely to reach the lower respiratory tract because most deposit in the nasal cavity and pharynx. Hence we encountered more local irritation symptoms of the upper respiratory tract and eyes.

The rate of emphysema and chronic bronchitis, which are components of COPD, is more common among current or former smoker workers compared to never smoker workers. We found higher byssinosis prevalence in individuals who inhaled hemp dust. This can be explained by the higher endotoxin content of hemp. To prove the presence of emphysema in these workers, further studies using more sophisticated investigation tools including diffusion testing, static lung volume measurements and high resolution computed tomography (HRCT) are needed.

We found that endotoxin levels were very high in dust taken from many areas of the hemp factory with mean air concentrations expected to exceed $100 \mathrm{EU} / \mathrm{m}^{3}$. This significantly exceeds the recommended OELs of $50 \mathrm{EU} / \mathrm{m}^{3}$ from the Netherlands. These findings support previous studies about the relation of endotoxins and byssinosis [22-25,38]. Our findings also suggest that advanced stage byssinosis may lead to development of chronic bronchitis and emphysema which are both components of COPD.

The study has shown that byssinosis prevalence is higher in hemp workers, perhaps due to higher endotoxin content of hemp fibers. To the best of our knowledge, no prior study revealed a higher byssinosis prevalence in hemp workers. In older studies, Schwartz et al. showed that tumor necrosis factor $\alpha$ (TNF- $\alpha$ ), interleukin-6 (IL-6) and other cytokines were higher in nasal lavage fluid of mice exposed to grain dust [39]. Also, Shvedova et al. found that cotton dust induced elevated levels of IL-6, interferon $\gamma($ INF- $\gamma$ ) and TNF- $\alpha$ in bronchoalveolar lavage (BAL) fluid of mice [40]. Therefore, there is a necessity to perform further investigations with hemp dust on animals or humans, including evaluation of biomarkers of inflammation in BAL fluids, to clarify higher byssinosis prevalence in hemp workers.

\section{Limitations of our study}

We examined the pulmonary functions of workers by spirometry only once, unfortunately we could not measure before and after the work shift. In addition, we could not prove emphysema of the workers by thoracic high resolution computed tomography due to technical insufficiency. Also, we could not perform the routine blood tests of the workers.

\section{CONCLUSIONS}

Byssinosis is no longer a problem in most developed industrial countries due to the institution of strict occupational health standards and the exportation of jobs in the textile industry to developing countries. As an agricultural and industrial country, about 1/2 million workers are presently engaged in the textile sector in Turkey. Controlling byssinosis disease, which is threatening the health of workers in Turkey, will increase the productivity in manufacturing and also contribute to overall health in Turkey.

\section{ACKNOWLEDGMENTS}

We would like to thank Assoc. Prof. Ali Naci Yildiz, M.D. for advice on statistical points of survey and also thank Nurten Erdem, Ph.D. from ISGUM (National Institute of Occupational and Safety of Health Administration of Turkey) for conducting dust measurements in the factory. 


\section{REFERENCES}

1. Kennedy SM. Agents causing chronic airflow obstruction. In: Harber P, Schenker MB, Balmes JR, editors. Occupational and environmental respiratory disease. 1st ed. St Louis: Mosby-Year Book; 1996. p. 433-49.

2. Fishwick D, Bradshaw L, D'Souza W, Town I, Armstrong R, Pearce N, et al. Chronic bronchitis, shortness of breath, and airway obstruction by occupation in New Zealand. Am J Respir Crit Care Med. 1997;156:1440-6, http://dx.doi. org/10.1164/ajrccm.156.5.97-03007.

3. Francis HC, Prys-Picard CO, Fischwick D, Stenton C, Burge PS, Bradshaw LM, et al. Defining and investigating occupational asthma: A consensus approach. Occup Environ Med. 2007;64:361-5, http://dx.doi.org/10.1136/oem. 2006.028902 .

4. Baur X, Bakehe P, Vellguth H. Bronchial asthma and COPD due to irritants in the workplace - An evidence based approach. J Occup Med Toxicol. 2012;7:19, http://dx.doi.org/ 10.1186/1745-6673-7-19.

5. Ramazzini B. De morbis artificum diatriba (Diseases of workers). Am J Public Health 2001;91(9):1380-2, http://dx.doi. org/10.2105/AJPH.91.9.1380.

6. Prausnitz C. Investigations on respiratory dust disease in operatives in the cotton industry. Medical Research Council, Special Report Series, No. 212. London: His Majesty's Stationery Office; 1936. p. 72.

7. Schilling RSF. Byssinosis in the British cotton textile industry. Br Med Bull. 1950;7:52-6.

8. Niven RML, Pickering CAC. Byssinosis and related diseases. In: Mapp CE, editor. Occupational lung disorders. European respiratory monograph, 11. Sheffield: European Respiratory Society; 1999. p. 286-300.

9. Fishwick D, Fletcher AM, Pickering CAC, Niven MR, Faragher EB. Lung function in Lancashire cotton and manmade fibre spinning mill operatives. Occup Environ Med. 1996;53(1):46-50, http://dx.doi.org/10.1136/oem.53.1.46.

10. Schachter EN. Byssinosis and other textile dust-related lung disease. In: Rosenstock L, Cullen M, editors. Textbook of clinical occupational and environmental medicine. Philadelphia: W.B. Saunders Company; 1994. p. 209-24.

11. Bouhuys A, Zuskin E. Chronic respiratory disease in hemp workers: A follow-up study, 1967-1974. Ann Int Med. 1976;84:398-405, http://dx.doi.org/10.7326/0003-481984-4-398.

12. Zuskin E, Kanceljak B, Pokrajac D, Schahter EN, Witek TJ Jr. Respiratory symptoms and lung function in hemp workers. Br J Ind Med. 1990;47:627-32, http://dx.doi. org/10.1136/oem.47.9.627.

13. Gilson JC, Scott H, Hopwood BEC, Roch SA, McKeerrow $\mathrm{CB}$, Schilling RSF. Byssinosis: The acute effect on ventilatory capacity of dusts in cotton ginneries, cotton, sisal and jute mills. Br J Ind Med. 1962;19:9-18, http://dx.doi. org/10.1136/oem.19.1.9.

14. Noweir MH, Noweir KH, Myo Tint U, Win Z, Myint H. A comparative environmental and medical study of dust exposure in jute and cotton mills in Burma. J Egypt Public Health Assoc. 1990;65(3-4):349-75.

15. Nicholls PJ, Skidmore JW. Comparative study of the smooth muscle contractor activity of airborne dusts and of dustiness in cotton, flax, and jute mills. Br J Ind Med. 1975;32 (4):289-96, http://dx.doi.org/10.1136/oem.32.4.289.

16. Chattopadhyay BP, Saiyed HN, Mukherjee AK. Byssinosis among jute mill workers. Ind Health. 2003;41(3):265-72, http://dx.doi.org/10.2486/indhealth.41.265.

17. Mandal A, Majumder R. Pulmonary function of jute mill workers from West Bengal, India. Prog Health Sci. 2014;4(1):7-17.

18. Schachter EN. Respiratory effects and other disease patterns in the textile industry. In: Stellman JM, editor. Encyclopedia of occupational health and safety. Geneva: International Labour Organization; 2011 [cited 5 June 2015]. Available from: http://www.ilo.org/iloenc/part-xiv/textile-goods-industry/ item/891-respiratory-effects-and-other-disease-patterns-inthe-textile-industry.

19. Marek K, Zejda JE. Respiratory system. In: Stellman JM, editor. Encyclopedia of occupational health and 
safety. Geneva: International Labour Organization; 2011 [cited 5 Jun 2015]. Available from: http://www.ilo.org/iloenc/ part-i/respiratory-system/item/424-chronic-obstructive-pulmonary-disease.

20. Honeybourne D, Pickering CA. Physiological evidence that emphysema is not a feature of byssinosis. Thorax. 1986;41: 6-11, http://dx.doi.org/10.1136/thx.41.1.6.

21. Ghawabi EL. Respiratory functions and symptoms in workers exposed simultaneously to jute and hemp. Br J Ind Med. 1978;35:16-20, http://dx.doi.org/10.1136/oem.35.1.16.

22. Douwes J, Thorne PS, Pearce N, Heederik D. Bioaerosol health effects and exposure assessment: Progress and prospects. Ann Occup Hyg. 2003;47(3):187-200, http://dx.doi. org/10.1093/annhyg/meg032.

23. Spaan S, Schinkel J, Wouters IM, Preller L, Tielemans E, $\mathrm{Nij}$ ET, et al. Variability in endotoxin exposure levels and consequences for exposure assessment. Ann Occup Hyg. 2008; 52(5):303-16, http://dx.doi.org/10.1093/ annhyg/men024.

24. Shi J, Mehta AJ, Hang J, Zhang H, Dai H, Su L, et al. Chronic lung function decline in cotton textile workers: Roles of historical and recent exposures to endotoxin. Environ Health Perspect. 2010;118(11):1620-4, http://dx.doi. org/10.1289/ehp.0901178.

25. Sanandam MR. Impact of endotoxin on physiological responses of rat exposed to textile environment. Int J Pharm Appl. 2011;2(3):155-8.

26. Tokgoz M. [Byssinosis prevalence and dust levels in Izmir cotton industry] [dissertation]. Izmir: Aegean University; 1968.

27. Topuzoglu I. [Features of byssinosis as occupational disease in Turkey] [dissertation]. Ankara: Hacettepe University; 1974.

28. Altin R, Ozkurt S, Fisekci F, Cimrin AH, Zencir M, Sevinc $\mathrm{C}$. Prevalence of byssinosis and respiratory symptoms among cotton mill workers. Respiration. 2002;69:52-6, http://dx.doi.org/10.1159/000049370.

29. Simsek C, Kelesoglu A, Akkurt I, Ersoy N, Ejder SS. [Pulmonary effects of dust among cotton thread workers]. Tuberc Thorax. 1996;44(1):6-11. Turkish.
30. Sahin U, Akkaya A, Unlu M, Gurbuz H. [An investigation of respiratory symptoms and pulmonary function tests in cotton thread factory workers]. Solunum. 1998;9(1):129-42. Turkish.

31. Rylander R, Peterson Y, Donham KJ. Questionnaire evaluating organic dust exposure. Am J Ind Med. 1990;17:121-6, http://dx.doi.org/10.1002/ajim.4700170142.

32. World Health Organization. Recommended health-based occupational exposure limits for respiratory irritants. Report of a WHO study group: Technical Report Series 707. Geneva: The Organization; 1984.

33. National Institute for Occupational Safety and Health. Occupational exposure to cotton dust. Criteria for a recommended standard. Washington (DC): U.S. Department of Health Education and Welfare, Center for Disease Control, National Institute for Occupational Safety and Health; 1974 (revised 1996). p. 75-118.

34. 29 C.F.R. Sect. 1910.1043. Cotton Dust. Washington (DC): Occupational Safety and Health Administration; 2000.

35. Thorne PS, Reynolds SJ, Milton DK, Bloebaum PD, Zhang X, Whitten P, et al. Field evaluation of endotoxin air sampling assay methods. Am Ind HygAssoc J. 1997;58: 792-9, http://dx.doi.org/10.1080/15428119791012298.

36. Su YM, Su JR, Sheu Y, Loh CH, Liou SH. Additive effect of smoking and cotton dust exposure on respiratory symptoms and pulmonary function of cotton textile workers. Ind Health. 2003;41:109-15, http://dx.doi.org/10.2486/indhealth.41.109.

37. Takemura Y, Kishimoto T, Takigawa T, Kojima S, Wang BL, Sakano N, et al. Effects of mask fitness and worker education on the prevention of occupational dust exposure. Acta Med Okayama. 2008;62(2):75-82.

38. Lai PS, Hang JQ, Zhang FY,Lin X, Zheng BY, Dai HL, et al. Gender differences in the effect of occupational endotoxin exposure on impaired lung function and death: The Shanghai Textile Worker Study. Occup Environ Med. 2014; 71:118-25, http://dx.doi.org/10.1136/oemed-2013-101676.

39. Schwartz DA, Thorne PS, Jagielo PJ, White GE, Bleuer SA, Frees KL. Endotoxin responsiveness and grain dust- 
induced inflammation in the lower respiratory tract. Am J Physiol. 1994;267(5):609-17.

40. Shvedova AA, Satoh T, Tollerud D, Guevarra L, Karol MH. Elevated levels of IL-6, INF- $\gamma$, and TNF- $\alpha$ in mice in response to cotton dust are modulated by anti-TNF- $\alpha$ antiserum. Exp Lung Res. 1996;22(2):149-61, http://dx.doi. org/10.3109/01902149609050844.

This work is available in Open Access model and licensed under a Creative Commons Attribution-NonCommercial 3.0 Poland License - http://creativecommons.org/ licenses/by-nc/3.0/pl/deed.en. 